\title{
Sistem Pendukung Keputusan Dalam Menentukan Karyawan Terbaik Menggunakan Metode Simple Additive Weighting
}

\author{
Qibran Noval' ${ }^{1}$ Yopi Handrianto ${ }^{2}$, Hendra Supendar ${ }^{3}$ \\ ${ }^{1}$ Program Studi Sistem Informasi/ STMIK Nusa Mandiri Jakarta \\ e-mail: qibran50@gmail.com \\ ${ }^{2,3}$ Fakultas Teknik \& Informatika/Universitas Bina Sarana Informatika \\ e-mail: ${ }^{2}$ yopi.yph@bsi.ac.id, ${ }^{3}$ hendra.hds@bsi.ac.id

\begin{tabular}{ccc}
\hline Diterima & Direvisi & Disetujui \\
$08-05-2020$ & $13-05-2020$ & $20-05-2020$ \\
\hline
\end{tabular}

\begin{abstract}
Abstrak - Peningkatan mutu dalam penyeleksian karyawan yang dilakukan oleh Divisi Sumber Daya Manusia Perusahaan menyebabkan karyawana terus berupaya dalam meningkatkan kompetensi dirinya. Untuk mengukur kinerja karyawan diperlukan suatu sistem pendukung yang dapat mengukur terhadap kinerja karyawan dengan memberikan penilaian kinerja terhadap karyawan tersebut, sehingga perusahaan dapat melakukan sistem penilaian secara objektif kepada setiap karyawan dengan harapan perusahaan memberikan transparansi terhadap penilaian yang dilakukan terhadap kompetensi dan kualitas karyawan sesuai dengan kebutuhannya. Sistem Pendukung Keputusan ini dibuat untuk Memberikan solusi dan membantu Manajer Sumber Daya Manusia dalam menentukan karyawan terbaik pada PT. Persada Nusantara Telekomunikasi. Metode Simple Additive Weighting (SAW) dipilih sebagai metode yang digunakan sebagai sistem pendukung keputusan untuk memilih karyawan terbaik. Metode Simple Additive Weighting merupakan suatu metode penjumlahan terbobot dari rating kinerja pada setiap alternatif pada semua atribut. Hasil dari sistem penunjang keputusan ini diharapkan memberi suatu pilihan alternatif yang dimiliki Divisi Sumber Daya Manusia sebagai suatu solusi dalam menentukan karyawan terbaik yang ada diperusahaan.
\end{abstract}

Kata Kunci: Sistem Pendukung Keputusan, Karyawan Terbaik, Simple Additive Weighting.

\begin{abstract}
Quality improvement in employee selection conducted by the Company's Human Resources Division causes employees to continue working to improve their competence. To measure employee performance we need a support system that can measure employee performance by providing performance appraisals of these employees, so the company can conduct an objective assessment system for each employee in the hope that the company provides transparency on assessments made to employee competencies and quality in accordance with their needs. This Decision Support System was created to provide solutions and assist the Human Resources Manager in determining the best employees at PT. Persada Nusantara Telekomunikasi. The Simple Additive Weighting (SAW) method was chosen as the method used as a decision support system for selecting the best employees. The Simple Additive Weighting method is a weighted sum of the performance ratings for each alternative on all attributes. The results of this decision support system are expected to provide an alternative choice owned by the Human Resources Division as a solution in determining the best employees in the company.
\end{abstract}

Keywords: Decision Support System, The Best Employee, Simple Additive Weighting.

\section{PENDAHULUAN}

"Karyawan merupakan salah satu sumber daya yang digunakan sebagai alat penggerak dalam memajukan suatu perusahaan. Kinerja karyawan cukup berpengaruh dalam keuntungan yang didapat oleh suatu perusahaan tersebut" (Triwahyuni et al. 2015). Karyawan adalah salah satu hal penting yang menunjang sebuah perusahaan, dimana apabila setiap karyawan mempunyai standar kualifikasi dan kompetensi yang ditetapkan oleh perusahaan maka produktivitas perusahaan akan stabil dan produktifitas perusahaan semakin baik (Safitri \& Tinus Waruwu, 2017)

Pada perusahaan, Salah satu elemen yang sangat penting adalah Sumber Daya Manusia (SDM). Pengelolaan SDM dari suatu perusahaan sangat mempengaruhi aspek-aspek penentu keberhasilan kerja dan pencapaian target dari perusahaan tersebut. Karenanya jika SDM dapat diorganisir dengan baik, maka diharapkan perusahaan dapat menjalankan semua proses usahanya dengan baik.(Masri, 2016). Banyaknya karyawan yang ada pada perusahaan 
membuat proses penilaian yang dilakukan terkadang menjadi sulit untuk dilakukan dan hasil yang dirasakan kurang tepat menjadikan suatu permasalahan yang ada pada proses dalam menentukan karyawan terbaik diperusahaan (Fitriah \& Irfiani, 2018)

PT. Persada Nusantara Telekomunikasi melakukan pemilihan karyawan terbaik untuk memacu semangat karyawan dalam meningkatkan dedikasi dan kinerjanya. Sebagai bentuk apresiasi atas karyawan yang telah melaksanakan pekerjaannya dengan baik. Apresiasi tersebut diharapkan juga dapat menambah semangat karyawan dalam bekerja. Penentuan karyawan terbaik di PT. Persada Nusantara Telekomunikasi selama ini yaitu hanya subjektifitas. Jadi jika karyawan diberikan penghargaan dikarenakan pada suatu kriteria tanpa melihat kriteria penilaian yang lainnya yaitu seperti kedisiplinan, kerajinan, tanggung jawab dan lain-lain. Subjektifitas tersebut biasanya terjadi untuk mengurangi kesulitan dalam proses pengambilan keputusan akibat banyaknya pilihan (alternatif).

Sistem merupakan suatu kesatuan usaha yang terdiri dari beberapa bagian yang saling berkaitan satu dengan lainnya yang berusaha mencapai suatu tujuan atau goal dalam suatu lingkungan (environment) kompleks (Manahan, 2016). "Keputusan merupakan hasil dari proses memilih pilihan terbaik diantara beberapa alternatif yang telah tersedia. Pada proses pengambilan keputusan, kita akan mencurahkan segala pemikiran dan melakukan kegiatan yang diperlukan untuk mendapatkan pilihan yang terbaik. Kegiatan yang diperlukan adalah mengumpulkan data dan informasi yang diperlukan serta menentukan metode pengambilan keputusan yang akan digunakan sebagai dasar untuk mengambil keputusan" (Diana, 2018).

Sistem pendukung keputusan atau SPK merupakan suatu sistem yang digunakan dalam mendukung dan membantu level manajemen dalam melakukan decision making pada situasi semiterstruktur dan tidak terstruktur (Nardiono, 2017). Metode yang digunakan sebagai sistem pendukung keputusan dalam menentukan karyawan terbaik pada PT. Persada Nusantara Telekomunikasi adalah metode Simple Additive Weighting.

\section{METODOLOGI PENELITIAN}

Metodologi penelitian dalam penelitian ini digambarkan pada bagan dibawah ini,

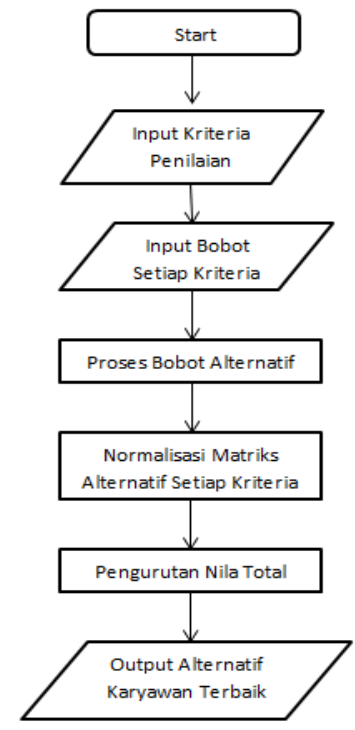

Sumber : (Simatupang, 2018)

Gambar 1. Metodologi Penelitian

Menurut Kusumadewi dalam (Nofriansyah \& Defit, 2017) "Metode Simple Additive Weighting sering juga dikenal dengan istilah metode penjumlahan terbobot. Sedangkan secara mendasar, metode Simple Additive Weighting adalah menemukan penjumlahan terbobot dari kinerja yang telah ditetapkan pada setiap alternatif di setiap atribut (Nofriansyah \& Defit, 2017). Metode Simple Additive Weighting merupakan metode yang banyak digunakan dalam pengambilan keputusan yang memiliki banyak atribut. Metode Simple Additive weighting membutuhkan proses normalisasi dengan semua rating alternatif yang ada.

Konsep dasar metode Simple Additive Weighting adalah mencari penjumlahan terbobot dengan rating kinerja pada setiap alternatif pada semua atribut. Metode Simple Additive Weighting biasanya digunakan untuk menyelesaikan masalah penyeleksian dalam sebuah sistem pengambilan keputusan yang memiliki banyak atribut (Fiqih \& Kusnadi, 2017).

Tahapan perhitungan menggunakan Rumus sebagai berikut :

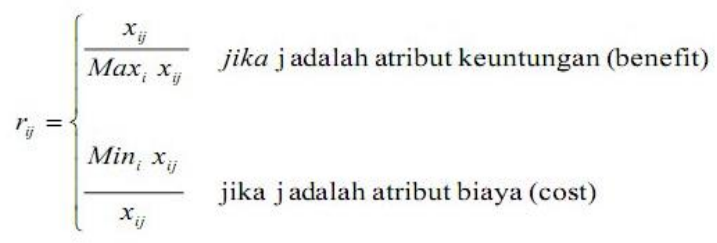

Keterangan:

$\mathrm{Rij}=$ Nilai rating kinerja ternormalisasi

$\mathrm{Xij}=$ Nilai atribut yang dimiliki dari setiap kriteria

Maxi $x i j=$ Nilai terbesar dari setiap kriteria

Mini $x i j=$ Nilai terkecil dari setiap kriteria 
Benefit $=$ Jika nilai terbesar adalah terbaik

Cost $=$ Jika nilai terkecil adalah terbaik

Nilai prefensi alternatif untuk setiap alternatif (Vi) diberikan sebagai :

$$
\mathrm{V}_{\mathrm{i}}=\sum_{\mathrm{j}=1}^{\mathrm{n}} \mathrm{W}_{\mathrm{j}} \mathbf{r}_{\mathrm{ij}}
$$

Keterangan :

$\mathrm{Vi} \quad=$ rangking untuk setiap alternatif

$\mathrm{N} \quad=$ banyaknya jumlah alternatif

$\mathrm{Wj} \quad=$ Nilai bobot dari setiap kriteria

Rij = Nilai rating kinerja ternormalisasi

Bila Nilai Vi rule yang lebih besar menjadi indikator bahwa alternatif Ai lebih terpilih.

Penelitian yang dilakukan dilakukan dengan pengamatan secara langsung di PT. Persada Nusantara Telekomunikasi untuk mendapatkan data dan informasi yang diperlukan. Metode yang dilakukan adalah dengan metode wawancara, observasi dan studi pustaka. Sampel dalam penelitian ini adalah data karyawan pada PT. Persada Nusantara Telekomunikasi, untuk menentukan jumlah sampel yang akan digunakan penelitian ini menggunakan sampel jenuh dikarenakan jumlah pupulasi relatif kecil kurang dari 30 orang. "Sampling jenuh merupakan suatu metode atau teknik penentuan sampel apabila semua anggota populasi digunakan sebagai sampel" (Sugiyono, 2015). Hal ini sering dilakukan bila jumlah populasi relatif kecil, kurang dari 30 orang, atau penelitian yang ingin membuat generelalisasi dengan kesalahan yang sangat kecil. Nama lain sampel jenuh yaitu sensus, dimana semua anggota populasi dijadikan sampel" (Sugiyono, 2015).

\section{HASIL DAN PEMBAHASAN}

Berikut digambarkan struktur hierarki pada Simple Aditive Sampling dalam menentukan karyawan terbaik pada PT. Persada Nusantara Telekomunikasi,

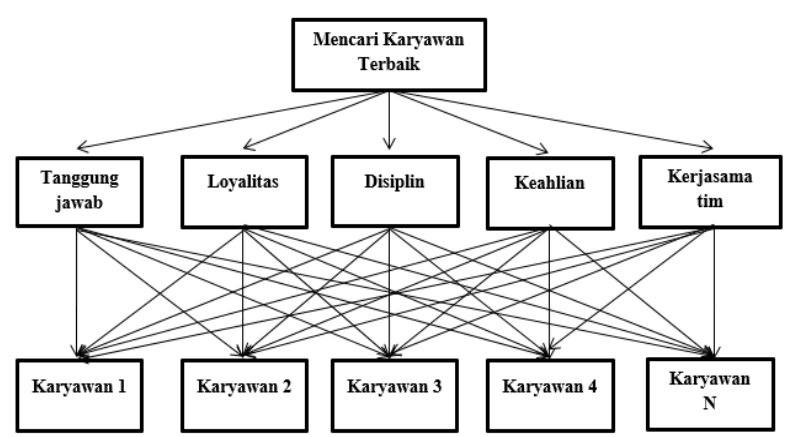

Sumber : Penelitian (2019)

Gambar 2. Struktur Hierarki Pemilihan Karyawan Terbaik
Langkah penyelesaian dalam mencari karyawan terbaik dengan menggunakan metode Simple Aditive Weighting adalah :

1. Dalam penyelesaian pemilihan pegawai terbaik diperlukan beberapa kriteria dan bobot untuk melakukan perhitungan. Hasil dari penelitian yang terdiri dari bobot dan kriteria yang dibutuhkan untuk menentukan siapa yang akan terseleksi sebagai pegawai yang berkinerja terbaik. Adapun kriterianya antara lain:

Tabel 1. Kode dan Ketentuan Kriteria Penilaian

\begin{tabular}{|c|c|}
\hline \multicolumn{2}{c}{ Karyawan } \\
Kriteria & Ketentuan \\
Kriteria \\
C1 & $\begin{array}{c}\text { Tanggung } \\
\text { Jawab }\end{array}$ \\
\hline C2 & Disiplin \\
\hline C3 & Loyalitas \\
\hline C4 & Keahlian \\
\hline C5 & Kerjasama \\
& Tim \\
\hline
\end{tabular}

Sumber: PT. Persada Nusantara Telekomunikasi (2019)

2. Menentukan Penggolongan kriteria .

Berikut diberikan rincian untuk penggolongan kriteria yang diberikan untuk penilaian karyawan terbaik.

Tabel 2. Penggolongan Kriteria

\begin{tabular}{|c|c|c|}
\hline Kriteria & Benefit & Cost \\
\hline Tanggung jawab & $\sqrt{ }$ & \\
\hline Disiplin & $\sqrt{ }$ & \\
\hline Loyalitas & $\sqrt{ }$ & \\
\hline Keahlian & $\sqrt{ }$ & \\
\hline Kerjasama Tim & $\sqrt{ }$ & \\
\hline Sumber: PT. Persada Nusantara Telekomunikasi
\end{tabular}
(2019)

3. Menentukan Nilai Bobot.

Selanjutnya adalah memberikan bobot pada masing-masing kriteria, seperti pada tabel dibawah ini.

Tabel 3. Bobot/Nilai Kriteria

\begin{tabular}{|c|c|c|}
\hline Kode & Range & Bobot \\
\hline $\mathrm{C} 1$ & 15 & 0,10 \\
\hline $\mathrm{C} 2$ & 15 & 0,15 \\
\hline
\end{tabular}




\begin{tabular}{|l|l|l|}
\hline C3 & 25 & 0,20 \\
\hline C4 & 25 & 0,25 \\
\hline C5 & 20 & 0,30 \\
\hline
\end{tabular}

Sumber : PT. Persada Nusantara Telekomunikasi (2019)

4. Setelah diberikan kriteria pembobotan dari masing-masing kriteria dari tanggung jawab, disiplin, loyalitas, keahlian dan kerjasama tim, maka didapatkan rating kecocokan alternatif seperti pada tabel dibawah ini.

Tabel 4. Rating Kecocokan

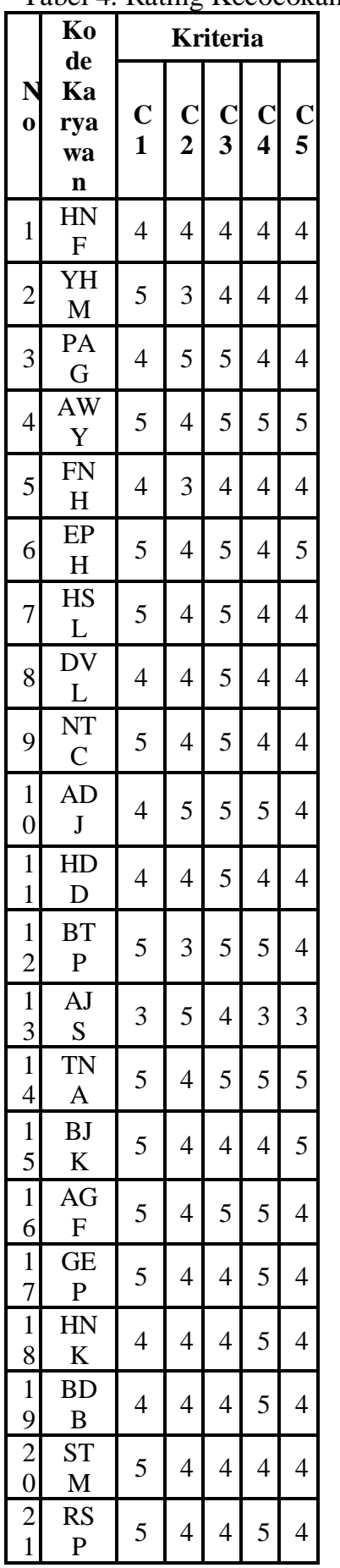

\begin{tabular}{|c|c|c|c|c|c|c|}
\hline & $\begin{array}{c}\text { RP } \\
\text { E }\end{array}$ & 5 & 4 & 4 & 4 & 4 \\
\hline & $\begin{array}{c}\mathrm{HR} \\
\mathrm{M}\end{array}$ & 4 & 4 & 4 & 4 & 3 \\
\hline 4 & IGS & 5 & 4 & 5 & 5 & 4 \\
\hline 2 & $\begin{array}{c}\mathrm{HD} \\
\mathrm{M}\end{array}$ & 5 & 4 & 5 & 4 & 4 \\
\hline 6 & IRS & 5 & 4 & 5 & 4 & 4 \\
\hline $\begin{array}{l}2 \\
7 \\
\end{array}$ & $\begin{array}{c}\mathrm{YM} \\
\mathrm{K} \\
\end{array}$ & 4 & 4 & 4 & 4 & 4 \\
\hline \begin{tabular}{|l|}
2 \\
8 \\
\end{tabular} & $\begin{array}{c}\mathrm{BN} \\
\mathrm{G}\end{array}$ & 5 & 4 & 4 & 5 & 4 \\
\hline $\begin{array}{l}2 \\
9 \\
\end{array}$ & $\begin{array}{c}\mathrm{VN} \\
\mathrm{I} \\
\end{array}$ & 5 & 4 & 4 & 5 & 4 \\
\hline \begin{tabular}{l|}
3 \\
0
\end{tabular} & $\begin{array}{c}\mathrm{MI} \\
\mathrm{B}\end{array}$ & 5 & 4 & 4 & 5 & 4 \\
\hline
\end{tabular}

Sumber : Penelitian (2019)

5. Selanjutnya adalah Menentukan matrix keputusan X, yang dibentuk dari tabel diatas. Maka didapatkan sebagai berikut,

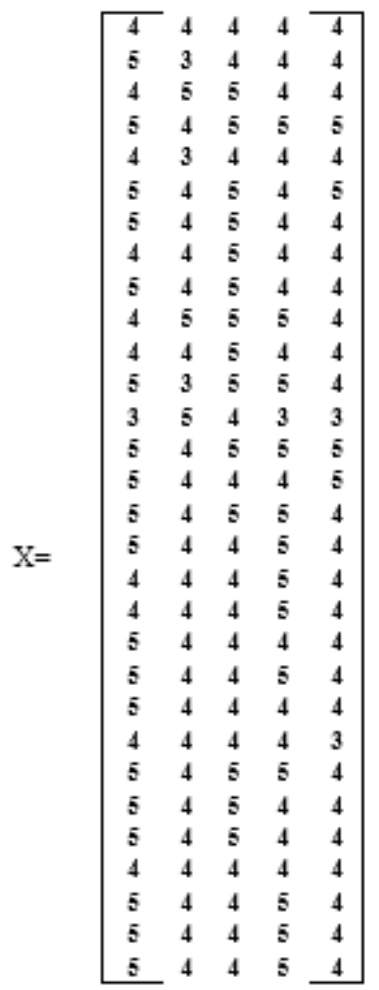

Dari nilai matrix kemudian dibuat ditentukan nilai ternormalisasi $\mathrm{R}$ dengan menggunakan rumus sebagai berikut:

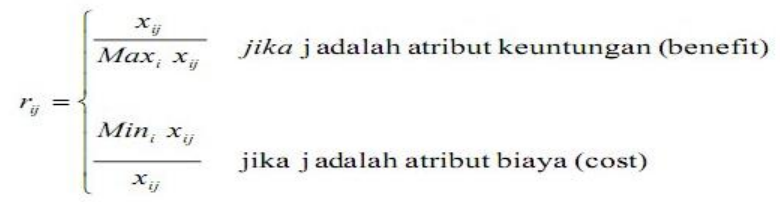

Keterangan:

$\mathrm{Rij}=$ Nilai rating kinerja ternormalisasi $\mathrm{Xij}=$ Nilai atribut yang dimiliki dari setiap kriteria 
Maxi xij = Nilai terbesar dari setiap kriteria Mini xij = Nilai terkecil dari setiap kriteria Benefit $=$ Jika nilai terbesar adalah terbaik Cost $=$ Jika nilai terkecil adalah terbaik

1. Penentuan matrix $\mathrm{R}$ berdasarkan kriteria sebagai berikut, kriteria pertama yaitu tanggung jawab (Benefit) :

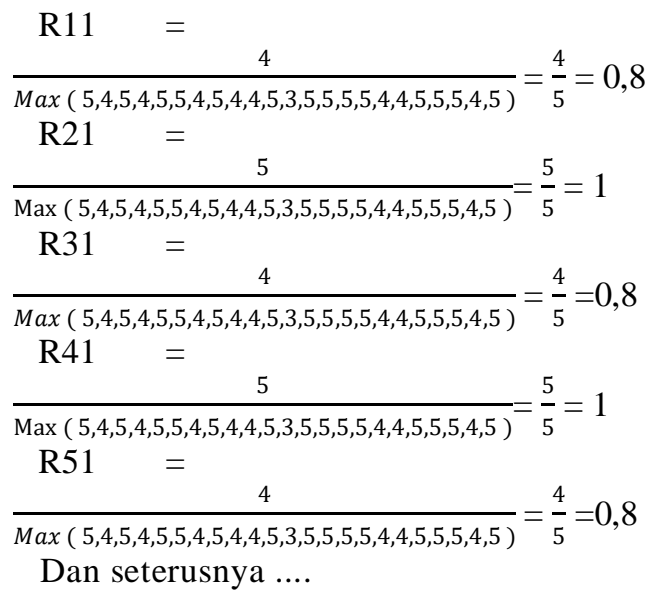

2. Kriteria kedua yaitu loyalitas (Benefit),

$\mathrm{R} 13=$

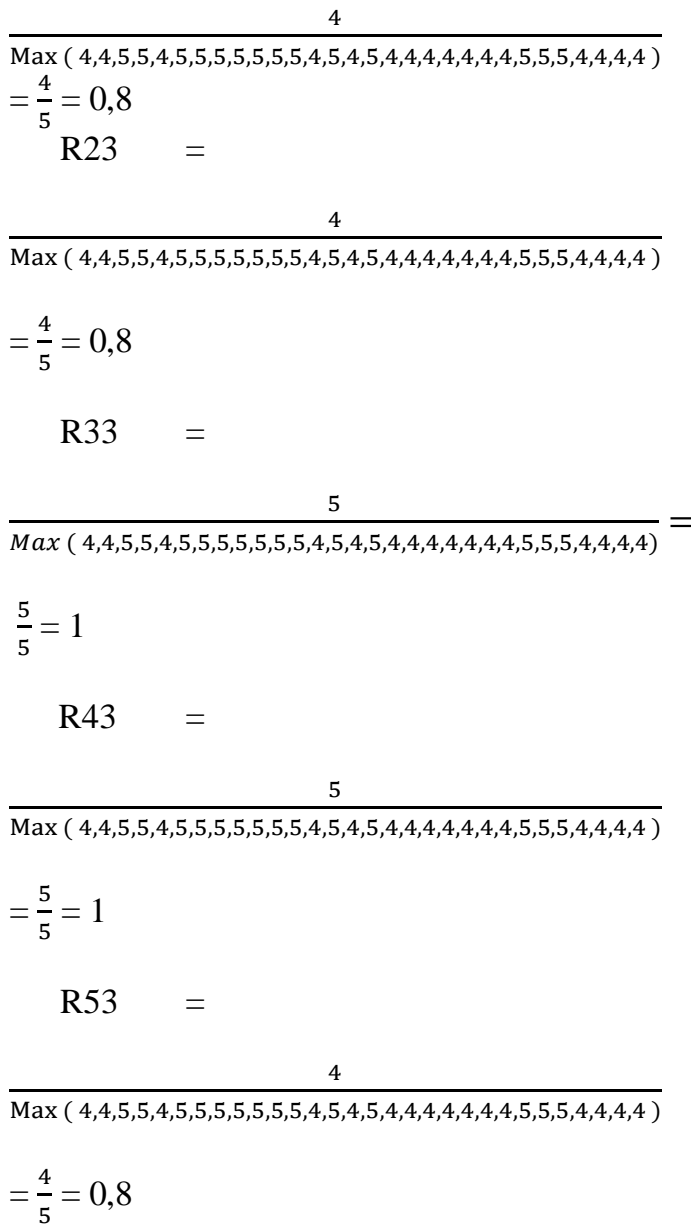

Dan seterusnya ....
Sehingga dari hasil perhitungan diatas maka didapatkan matriks ternormalisasi (R) sebagai berikut :

$R=$\begin{tabular}{cccccc}
0,8 & 0,8 & 0,8 & 0,8 & 0,8 \\
1 & 0,6 & 0,8 & 0,8 & 0,8 \\
0,8 & 1 & 1 & 0,8 & 0,8 \\
1 & 0,8 & 1 & 1 & 1 \\
0,8 & 0,6 & 0,8 & 0,8 & 0,8 \\
1 & 0,8 & 1 & 0,8 & 1 \\
1 & 0,8 & 1 & 0,8 & 0,8 \\
0,8 & 0,8 & 1 & 0,8 & 0,8 \\
1 & 0,8 & 1 & 0,8 & 0,8 \\
0,8 & 1 & 1 & 1 & 0,8 \\
0,8 & 0,8 & 1 & 0,8 & 0,8 \\
1 & 0,6 & 1 & 1 & 0,8 \\
0,6 & 1 & 0,8 & 0,6 & 0,6 \\
1 & 0,8 & 1 & 1 & 1 \\
1 & 0,8 & 0,8 & 0,8 & 1 \\
1 & 0,8 & 1 & 1 & 0,8 \\
1 & 0,8 & 0,8 & 1 & 0,8 \\
0,8 & 0,8 & 0,8 & 1 & 0,8 \\
0,8 & 0,8 & 0,8 & 1 & 0,8 \\
1 & 0,8 & 0,8 & 0,8 & 0,8 \\
1 & 0,8 & 0,8 & 1 & 0,8 \\
1 & 0,8 & 0,8 & 0,8 & 0,8 \\
0,8 & 0,8 & 0,8 & 0,8 & 0,6 \\
1 & 0,8 & 1 & 1 & 0,8 \\
1 & 0,8 & 1 & 0,8 & 0,8 \\
1 & 0,8 & 1 & 0,8 & 0,8 \\
0,8 & 0,8 & 0,8 & 0,8 & 0,8 \\
1 & 0,8 & 0,8 & 1 & 0,8 \\
1 & 0,8 & 0,8 & 1 & 0,8 \\
1 & 0,8 & 0,8 & 1 & 0,8 \\
\hline & & & &
\end{tabular}

6. Langkah terakhir, yaitu proses pencarian perankingan dengan memasukan setiap kriteria dan nilai bobot yang digunakan yaitu $\mathrm{W}=[0,10$ $\left.\begin{array}{llll}0,15 & 0,20 & 0,25 & 0,30\end{array}\right]$.

$$
\begin{aligned}
& \mathrm{V} 1=(0,10 \times 0,8)+(0,15 \times 0,8)+(0,20 \times 0,8) \\
& +(0,25 \times 0,8)+(0,30 \times 0,8) \\
& =0,08+0,12+0,16+0,2+0,24 \\
& =0,8 \\
& \text { V2 }=(0,10 \times 1)+(0,15 \times 0,6)+(0,20 \times 0,8)+ \\
& (0,25 \times 0,8)+(0,30 \times 0,8) \\
& =0,10+0,09+0,16+0,2+0,24 \\
& =0,79 \\
& \mathrm{~V} 3=(0,10 \times 0,8)+(0,15 \times 1)+(0,20 \times 1)+ \\
& (0,25 \times 0,8)+(0,30 \times 0,8) \\
& =0,08+0,15+0,20+0.2+0,24 \\
& =0,87 \\
& \text { V4 }=(0,10 \times 1)+(0,15 \times 0,8)+(0,20 \times 1)+ \\
& (0,25 \times 1)+(0,30 \times 1) \\
& =0.10+0,12+0.2+0,25+0,30 \\
& =0,97 \\
& \text { V5 }=(0,10 \times 0,8)+(0,15 \times 0,6)+(0,20 \times 0,8) \\
& +(0,25 \times 0,8)+(0,30 \times 0,8) \\
& =0,08+0,09+0,16+0,2+0,24 \\
& =0,77
\end{aligned}
$$

Dan seterusnya ....

Jika secara keseluruhan sudah dihitung sesuai bobot maka akan mendapatkan hasil perangkingan yang telah dipilih dan diurutkan sebagai karyawan 
terbaik sebanyak 3 orang karyawan sebagai berikut : pertama, karyawan dengan kode AWY menjadi karyawan terbaik dengan point 0,97 lalu kedua, karyawan dengan kode TNA dengan point 0,97 dan ketiga, karyawan dengan kode EPH dengan point 0,92 .

\section{KESIMPULAN}

Dari hasil penelitian yang dilakukan, kesimpulan yang dapat diambil bahwa penilaian kinerja dari karyawan dapat diperluas lingkupnya dengan memberikan suatu kriteria yang diperlukan oleh PT. Persada Nusantara Telekomunikasi. Kesimpulan lainnya adalah bahwa pemilihan karyawan terbaik tidak diindikasikan kepada lamanya seorang karyawan bekerja di perusahaan, tetapi harus memiliki nilai kompentensi yang baik sesuai dengan kriteria yang ditetapkan oleh perusahaan.

Pada proses yang dilakukan dalam menentukan rnagking karyawan melalui perhitungan menggunakan metode Simple Additive Weighting yang dimulai dari pemberian nilai kriteria, pemberian bobot, rating kecocokan, normalisasi dan perangkingan. Berdasarkan hasil analisis perhitungan yang dilakukan dalam penelitian ini, karyawan pada PT. Persada Nusantara Telekomunikasi yang memiliki nilai terbaik adalah karyawan dengan kode AWY.

Untuk penelitian lanjutan, peneliti dapat memberikan suatu kriteria yang diperlukan sehingga penelitian yang akan dilakukan sesuai dengan kebutuhan perusahaan. Agar lebih mendapatkan data yang akurat, proses perhitungan dapat menggunakan suatu aplikasi yang dibangun sehingga dapat membantu peneliti lain dalam melakukan pengolahan data agar hasil yang diperoleh lebih baik.

\section{REFERENSI}

Diana. (2018). Metode \& Aplikasi Sistem Pendukung Keputusan. Deepublish.

Fiqih, M., \& Kusnadi, Y. (2017). Sistem Pendukung Keputusan Pemilihan Dosen Berprestasi Dengan Metode Simple Additive Weighting. Information System For Educators And Professionals, 2(1), 41-50. http://ejournalbinainsani.ac.id/index.php/ISBI/article/view/6
$86 / 571$

Fitriah, A., \& Irfiani, E. (2018). Sistem Pendukung Keputusan Pemilihan Pegawai Terbaik PT Pegadaian Jakarta Dengan Metode Simple Additive Weighting. Information System for Educators and Professionals, 2(2), 105-114. http://ejournal-

binainsani.ac.id/index.php/ISBI/article/view/7 47

Manahan, O. (2016). Perancangan Dan Pembuatan Sistem Pendukung Keputusan Penentuan Karyawan Terbaik Dengan Metode Saw Pada Pt Iss Indonesia Cabang Medan. 19(1), 44-52

Masri, M. (2016). Penentuan Karyawan Terbaik Dengan Metode Simple Additive Weighting (PDAM Tirta Silaupiasa). JET (Journal of Electrical Technology), 1(1), 36-41. https://jurnal.uisu.ac.id/index.php/jet/article/vi ew/187

Nardiono. (2017). Komparasi Metode Simple Additive Weightin ( Saw ) Dan Metode Weighted Product ( Wp ) Dalam Menentukan Karyawan Terbaik ( Studi Kasus: Pt . Matrixnet Global Indonesia ). Vol. 2, No, 2533.

Nofriansyah, D., \& Defit, S. (2017). Multi Criteria Decision Making (MCDM) pada sistem pendukung keputusan.

Safitri, K., \& Tinus Waruwu, F. (2017). Sistem Pendukung Keputusan Pemilihan Karyawan Berprestasi Dengan Menggunakan Metode Analytical Hieararchy Process (Studi Kasus : PT.Capella Dinamik Nusantara Takengon). 1(1), 12-16.

Simatupang, J. (2018). Sistem Pendukung Keputusan Penentuan Karyawan Terbaik Menggunakan Metode Saw Studi Kasus Amik Mahaputra Riau. Jurnal Intra-Tech, 2(1), 73-82.

Sugiyono. (2015). Metode penelitian pendekatan kuantitatif, kualitatif dan R\&DNo Title. In Metode penelitian pendekatan kuantitatif, kualitatif dan $R \& D$ (pp. 80-84). Alfabeta.

Triwahyuni, A., Septiawan, M. R., Rizal, \& Marsusilianti. (2015). Sistem Pendukung Keputusan Penentuan Karyawan Terbaik Carrefour Menggunakan Metode Simple Additive Weighting ( Saw ). 15(2), 66-80. 